\title{
Parental Competence Beliefs and Attributions for Achievement in Kindergarten: Effects on Parent Expectations
}

\author{
Georgia Stephanou (Corresponding author) \\ Department of Early Childhood Education, University of Western Macedonia, \\ 53100 Florina, Greece \\ E-mail: gstephanou@uowm.gr \\ Maria Doulkeridou \\ Department of Early Childhood Education, University of Western Macedonia, \\ 53100 Florina, Greece
}

Received: March 29, 2020 Accepted: April 30, 2020 Published: May 22, 2020

doi:10.5296/ijssr.v8i2.16766 URL: http://dx.doi.org/10.5296/ijssr.v8i2.16766

\begin{abstract}
The aim of this study was to examine (a) parental attributions for children's performance in language, mathematics and globally school in kindergarten, (b) whether parents' perceptions concerning their children's academic ability predict the children's school performance in kindergarten, the subsequent parental attributions, and the impact of school performance and parental attributions on parental expectations concerning their children's later school performance in the first primary school year, and (c) the role of the three sets of concepts (perceived academic ability, performance in kindergarten, and subsequent parent attributions) in the formulation of parent expectations. The participants were parents of 150 kindergarten children (80 girls, 70 boys), who were randomly recruited from 45 state kindergartens of various towns of Greece. The results revealed: (a) parents attributed their children's good performance to stable and, mainly, internal and personal controllable to the children's factors, (b) the higher parents estimated their children's ability, the better the children performed in the respective school subject, and the higher the parental attributions to internal, stable, personal controllable and external uncontrollable to the children's factors were, (c) variability in the effect of parents' perceptions of their children's ability on attributions and performance between and within school subjects, in favoring language, and least favoring general school
\end{abstract}




\section{Macrothink}

International Journal of Social Science Research

ISSN 2327-5510

2020, Vol. 8, No. 2

performance and (d) although parental perceived children's academic ability was the most powerful predictor of parents' expectations regarding their children's performance in grade one, both the children's past performance and the subsequent parental attributions accounted for a positive significant portion of the variance of it.

Keywords: parental attributions, parental beliefs, school performance 


\section{Introduction}

Past research from a variety of perspectives with children evident the important influences that parents have in their children's academic success (Duckworth, Peterson, Matthews, \& Kelly, 2007; Fornander \& Kearney, 2019; Garbacz, Herman, Thompson, \& Reinke, 2017; Hutchinson \& Yates, 2008; Lee, Daniels, \& Kissinger, 2006; Pomerantz, Grolnick, \& Price, 2005; Redding, 2006), although some studies have found no significant relationship between parent involvement and academic achievement (Okpala, Okpala, \& Smith, 2001; White, Taylor, \& Moss, 1992) and a few have even detected negative associations (Sui-Chu \& Willms, 1996). Moreover, as has been reported in various meta-analyses the magnitude of parental effects on children's academic achievement is consistently large enough to have a meaningful impact across the ethnic group, socioeconomic level, and grade level (Castro, Expósito-Casas, López-Martín, Lizasoain, Navarro-Asencio, \& Gaviria, 2015; Fan \& Chen, 2001; Jeynes, 2007; Ma, Shen, Krenn, Hu, \& Yuan, 2016; Saracho, 2002). Also, parental involvement factors have a longitudinal effect on children's academic development (Fan, 2001; Hong \& Ho, 2005). For example, it was found positive associations between parent involvement in preschool and kindergarten and reading achievement in kindergarten, and in eighth grade (Miedel \& Reynolds, 1999).

Due to the high importance of parent involvement, much research has focused on specifying the nature of parental involvement at school and the kinds of influence parents do have on different children outcomes (Boonk, Gijselaers, Ritzen, \& Brand-Gruwela, 2018 for a review). For example, some of the parents' behaviors that affect children's school success are book reading, homework, verbal interactions, parenting styles and practices, and attending school functions (Epstein, 1992; Darling \& Steinberg, 1993; Epstein \& Dauber, 1991; Hill \& Taylor, 2004; Ishak, Low, \& Lau, 2011; Soenens, Duriez, Vansteenkiste, \& Goossens, 2007; Stevenson \& Baker, 1987; Urdan, Solek, \& Schoenfelder, 2007; Wigfield, Byrnes, \& Eccles, 2006; Zentner \& Renaud, 2007). However, the mechanisms through which parent involvement exerts its influence on children's academic achievement have been not fully explained (Hill \& Craft, 2003; Topor, Keane, Shelton, \& Calkins, 2010). The existent research rather suggests that parents' emotions, beliefs, values and attitudes regarding education and the aspirations they hold for their children that affect their efforts to promote their children's school readiness and success (Englund, Luckner, Whaley, \& Egeland, 2004; Jones \& Prinz, 2005; Kaplan, Liu, \& Kaplan, 2001; Loughlin-Presnal \& Bierman, 2017; Rimm-Kaufman, Pianta, Cox, \& Bradley, 2003). Therefore, this study focuses on parents' beliefs about the causes of their children's academic outcomes, and their beliefs of children's academic ability and future achievement. Each of these three concepts is not only an important aspect of parental involvement but it has also a direct effect on a child's academic achievement.

Although a substantial amount of studies on parental involvement illustrates crucial role of parents in children's good start in formal education, a narrow number of investigations have examined the variables that are associated with the parental involvement in kindergarten for their role during the transition to primary school (Boonk et al., 2018; Taylor, Clayton, \& Rowley, 2004). This study focuses on the possible factors associating with the influences that 
parents have on children's live in kindergarten and their aspirations for their children's achievement in the first year of primary education.

Also, this study was involved in both general and specific subject areas because, while at the begging of the kindergarten studies specific subject areas are not a focus of the children's education, as the kindergarten studies pass mathematics and language become significant in children's school development (Natale, Aunola, \& Nurmi, 2009).

\subsection{Parental Attributions}

Weiner's $(1992,2000,2001,2003,2010)$ attribution theory, on which this study is based, represents a comprehensive theoretical framework for understanding motivation for achievement outcomes from the intrapersonal perspective, which refers to the attributions individuals make for their performance, and from the interpersonal perspective, which concerns the attributions made for outcomes experienced by others, and how perceptions of another's responsibility for an outcome contributes to other-directed emotions (gratitude, anger) and behaviors (punishment, support) (Schunk \& Zimmerman, 2006; Wand \& Hall, 2018). This theory has proved useful in examining how parents explain and evaluate their children's academic performance (Kinlaw, Kurtz-Costes, \& Goldman-Fraser, 2001; Natale et al., 2009; Rytkönen, Aunola, \& Nurmi, 2005; Sawrikar, Hawes, Moul, \& Dadds, 2019).

Parents are motivated to understand the cause of their child's behavior because such an understanding is crucial to how they socialize their children into academic life (Goodnow, 1988; Scott, 2018). Parents' beliefs about the causes of their children's academic outcomes influence their conceptions regarding the children's needs, motives, and limitations, which, in turn, affect parental affective and behavioral responses toward their children, and consequently, the development of children's academic skills (Dix \& Grusec, 1985; Georgiou \& Tourva, 2007; Sawrikar \& Dadds, 2018). For example, parental positive attributions enhance their expectations and aspirations concerning their children's performance (Murphey, 1992; Scott, 2018) as well as the child's academic performance (Aunola, Leskinen, Onatsu-Arvilommi, \& Nurmi, 2002; Parsons, Adler, \& Kaczala, 1982). Similarly, parental attributions of children' success to their adequate ability were positively related to higher levels of later academic performance in kindergarten and first grade (Natale et al., 2009). Moreover, as Natale et al. (2009, p. 15) mention, the transition from kindergarten to primary school is a particularly important period for the formation of parents' causal attributions, and for their impact on children's performance.

Although, an academic outcome could be attributed an infinite number of factors, ability, effort, task-difficulty and luck are the most prominent causes in describing the successful and unsuccessful event (Schunk \& Zimmerman, 2006; Weiner, 2010) but within parental attributions teacher competence appears more often than luck. Specifically, previous research on parental attributions indicates that parents usually attribute their children's success and failure to either ability or effort rather than to task difficulty or teacher competence (Cashmore \& Goodnow,1986; Natale et al., 2009; Rytkönen et al., 2005; Yee \& Eccles, 1988). 
However, after an achievement outcome, the causes per se are not crucial, as the location of the causes on attributional dimensions which have psychological and behavioral consequences. Hence, the present study focused on attributional dimensions. According to Weiner's theory, attributions are categorized into dimensions of locus of causality (internal/external to the person), stability (stable/unstable over time) and controllability (personal and external controllable/uncontrollable). Although all attributional dimensions are related to expectations and emotions, which, in turn, influence behavior, each of them has specific consequences (Berndsen \& Manstead, 2007; Stephanou, 2012; Weiner, 2005). Stability most impact on performance expectations and the emotions of hopefulness/hopelessness, controllability affects perceptions of personal responsibility and the social-related emotions, such as shame, anger, and gratitude. Locus of causality mainly influences perceptions of personal competence and the self-related emotions, such as pride in success.

Behaviors and emotions conveyed by parents might be interpreted by children as conveying parents' underlying attributional beliefs concerning their children's academic performance. For example, a parent who attributes his/her child's poor school performance to the child's low effort (internal, controllable and relative unstable) may ultimately be angry and reprimand the child. Parents' attributions may also influence their children's behavior at school. For instance, it was found that adult praise for effort or intelligence promotes children's mastery-orientation or performance- orientation respectively (Kamins \& Dweck, 1999; Mueller \& Dweck, 1998), which might, in turn, have an impact on children's subsequent performance (Natale et al., 2009).

Parents exhibit self-enhancing and self-saving biases (Dix \& Grusec, 1985; Graham \& Weiner, 1991) when making attributions for positive and negative child's outcomes. Precisely, parents tend to attribute their children's academic positive outcomes to internal, stable and dispositional factors to the child (ability), whereas they make references to unstable, external and situational factors for the child's negative outcomes (Dunton, McDevitt, \& Hess, 1988; Goodnow, 1988; Holloway \& Hess, 1985; Natale et al., 2009; Raty, Vanska, Kasanen, \& Karkkainen, 2002; Rytkönen et al., 2005). Such an attributional pattern sustains the good caretaker parental role (Sawrikar \& Dadds, 2018; Sawrikar et al., 2019). However, some studies have obtained different results. For example, Yee and Eccles (1988) found that parents attributed their children's success and failure to ability and to lack of effort respectively. Rytkönen et al. (2005) reported that, in preschool, parents attributed their children's success to ability and teaching, while when the children moved to primary school, they increasingly attributed their children's success to ability and failure to lack of effort. The latter finding stresses the child's responsibility to the academic performance, with certain consequences for future performance. In consistency with the above research evidence, Mau (1997) supports that when parents consider academic success and failure as a result of putting effort or not putting enough effort (internal, controllable), they are likely to encourage their children to work hard. It was also found that parental attribution of the child's achievement to the child's effort was positively associated with the child's actual achievement results (Georgiou, 2010). Moreover, students who perceived their parents emphasizing effort and academic 
achievement are more likely to be motivated than students whose parents did not value effort (Marchant, Sharon, Paulson, \& Rothlisberg, 2001). However, as Sawrikar and Dadds (2018) emphasize, this parental optimism attributional pattern may wane when parents estimate their children as blameworthy for problematic behaviors, and they attribute negative outcomes to internal, stable, and global to the child (Dix \& Lochman, 1990; Gretarsson \& Gelfand, 1988; Strassberg, 1995). Specifically, such attributional scheme is maladaptive in parenting, since it raises negative affective (angry) and behavioral responses (coercive parenting styles, harsh punishment) toward the child (Azar, 1997; Dix \& Gruse, 1985; Slep \& O’Leary, 1998) as well as it predicts negative outcomes for children and the development of child behavioral problems (Johnston, Hommersen, \& Seipp, 2009; Nix, Pinderhughes, Dodge, Bates, Pettit, \& McFadyen-Ketchum, 1999).

\subsection{Parents'Beliefs about Children's Competence and Future Academic Performance}

According to Wigfield and Eccles's (2000) expectancy-value model, which is one of the most influential frameworks to conceptualize achievement motivation (Meyer, Fleckenstein, \& Köller, 2019; Rosenzweig, Wigfield, \& Eccles, 2019), expectancy is defined as one's expectation for future success and is related to his/her competence beliefs. Specifically, while the expectancy beliefs are significant formulators of academic achievement behavior, they are influenced, among other factors, by the student's perceptions of his/her ability to do a task.

The findings from research in achievement behavior indicate the high expectations for success are related to task engagement, persistence in carrying out tasks, effective use of cognitive and metacognitive strategies, and successful performance (Eccles \& Wigfield, 2002; Efklides, 2001; Nuutila, Tuominen, Tapola, Vainikainen, \& Niemivirta, 2018; Rosenzweig et al., 2019; Stephanou, 2008). Similarly, past empirical studies evident that ability self-perception, playing, mainly, a motive role, is positively related to academic performance (Alves-Martins \& Peixoto, 2000; Eccles, 2009; Herrera, Al-Lal, \& Mohamed, 2020; Sewasew, \& Schroeders, 2019; Stephanou, 2004, 2006; Susperreguy, Davis-Kean, Duckworth, \& Chen, 2018), even after controlling for ability (Beane, 1999; Pintrich \& Schunk, 2002). Susperreguy, Davis-Kean, Duckworth and Chen (2018), analyzing three large-scale longitudinal datasets with children aged 11 to 15 , revealed that ability self-perceptions in math and reading predict later achievement in each respective domain. These results were replicated, after controlling for the effects of demographic factors, child characteristics (working memory, socio-emotional and behavior problems) and early achievement, across all levels of achievers and from early childhood to adolescence.

The existent literature regarding parents' expectations supports their significant role in a child's academic development. A study by Martini and Sénéchal (2012), for example, revealed that parent academic expectations were a unique contributor to children's school readiness and academic success, independently from the parent teaching efforts. Similarly, Sy and Schulenberg (2005) found that parent academic expectations at kindergarten entry predicted children's reading and math achievement in kindergarten, and in the first grade. Also, Gut, Reimannn, and Grob (2013) illustrated that parent academic expectations at school entry predicted children's grade point averages three years later. Yet, parents' expectations 
influence students' perceptions of their ability, and, then these perceptions have an impact on subsequent academic performance (Phillipson \& Phillipson, 2007). Also, prekindergarten children emergent literacy skills and self-directed learning by enhancing parent academic expectations (Loughlin-Presnal \& Bierman, 2017). Besides, expectancy beliefs originate in the individuals' perceptions of previous situations as well as socialization processes, including the ways that parents provide support (Wigfield \& Eccles, 1992).

In literature in parents' beliefs concerning their children's competence, Pomerantz and Dong (2006. p. 1) concurred that "parents' perceptions of children's academic competence play a powerful role in children's development in the academic arena...'. Herbert and Stipek (2005), for instance, reported the positive impact of parents' judgments of children's math competence on children's later perceptions of their math competence. Yet, a child, who assumes their parents estimate his/her competency in a certain domain as relatively low, may "live up" to those expectations (Tomasetto, Mirisola, Galdi, \& Cadinu, 2015) or "spillover" into his/her views and expectations of how much he/she should value certain academic domains, leading to low child's performance (Racz, Putnick, Esposito, \& Bornstein, 2019).

These competence perceptions are determined by other factors, such as attributions of past events. In Wigfield and Eccles's (1992) model, attributions are crucial to the formation of self-perception of competence and expectancies. However, there is a bi-directional relationship between ability self-perception and attributions (Weiner, 1992, 2010). For example, students, who estimate their ability in an academic task as low, are likely to attribute failure to stable, personal uncontrollable and internal factors (lack of ability), and success to unstable, personal uncontrollable and external factors (luck), whereas students, who perceived their ability as high, tend to attribute successful performance to internal, stable, personal controllable, and external uncontrollable factors (Stephanou, 2004, 2012; Schunk \& Zimmerman, 2006; Weiner, 2004, 2005).

While the individual association of the above parental variables with the child's academic performance has, relatively, satisfactorily examined, a limited number of researches have investigated the role of the relationship among these variables in the child's early school life.

\subsection{Aim and Hypotheses of This Study}

This study aimed to examine (a) parents' attributions concerning their children's general academic performance and performance in language and mathematics in kindergarten, (b) whether parents' perceptions of their children's academic ability predict the children's school performance in kindergarten, and their subsequent attributions, (c) if the three sets of concepts (perceived academic ability, performance in kindergarten, and subsequent attributions) have an impact on parental expectations concerning their children's later school performance in the first primary school year, and (d) whether the parents' perceptions of their children's academic ability will enhance the effect of school performance in kindergarten and the subsequent attributions on performance expectations.

The Hypotheses of this study were the following.

Parents' attributions about their children's school performance will mainly be associated with 
children (internal, controllable) - than to others (external, external controllable) - related factors (Hypothesis 1a). Furthermore, the higher the level of the children's school performance, the higher the parental attribution to children's stable, internal and controllable factors (Hypothesis 1b)

Parents' perceptions of their children's academic ability will have a positive effect on children's school performance in language, mathematics and general (Hypothesis 2), and on the subsequent parental attributions, mainly locus of causality (Hypothesis 3).

Parents' perceptions of their children's academic ability, children's school performance in kindergarten and parents' subsequent attributions (mainly, stability) will positively influence parents' expectations of their children's performance in the first primary school year across language, mathematics and general school (Hypothesis 4a). Parents' perceptions about children's academic ability in kindergarten will enhance the impact of the other two concepts on parental expectations for children's later school performance (Hypothesis 4b).

There would be school subject effect but no specific Hypothesis is estimated (Hypothesis 5).

\section{Method}

\subsection{Participants}

The participants in this research were parents of 150 kindergarten children (80 girls, and 70 boys), who had mean age of 5.35 years ( $\mathrm{SD}=.48$ months), and they were randomly recruited from 45 state kindergartens of various towns of Greece. The participating parents represented various socio-economical levels, and of them, $70 \%$ and $30 \%$ were mothers and fathers respectively.

\subsection{Measures}

A questionnaire with separate versions for mathematics, language, and general school performance was constructed. It comprised of four scales. The wording of the questions for the three options of school performance was the same except for the subject name.

The construction of all of the scales, expect for attributions scale, was based on previous similar researches (Eccles \& Wigfield, 2002; Nagy, Trautwein, Baumert, Koller, \& Garrett, 2006; Pintrich \& Schunk, 2002; Rosenzweig et al., 2019; Stephanou \& Mpiontini, 2017; Wigfield \& Eccles, 2002).

\subsubsection{Attributions}

Parents' attributions concerning their children's performance at school were examined via the slightly modified Causal Dimension Scale-II (CDSII, McAuley, Duncan, \& Russell, 1992). This scale has proven a reliable and valid research instrument in examining attributions for achievement school behavior in the Greek population (Stephanou, 2012). The parents wrote down the most important factor which, according to their opinion, influenced their children's school performance, how much this factor contributed to the given performance, and classified that cause along the attributional dimensions of locus of causality (internal/external causes to the child), stability (stable/unstable causes over time), personal controllability 
(personal controllable/uncontrollable causes by the child) and external controllability (controllable/uncontrollable causes by others). Each subscale consists of three items, ranging from the negative pole 1 to the positive pole 9 (from $1=$ not at all stable to $9=$ totally stable). Cronbach's alpha regarding parental attributions for the children's general school performance were .85 for locus of causality, .79 for stability, .82 for personal controllability, and .74 for external controllability. In mathematics performance, Cronbach's alpha were $.80, .82, .78$ and .75 for locus of causality, stability, personal controllability and external controllability, respectively. Cronbach's alpha regarding language performance were $.79, .84, .74$ and .78 for locus of causality, stability, personal controllability and, external controllability, respectively.

\subsubsection{Ability Perceptions}

The parents' perceptions concerning their children's ability were examined by four questions ("How good is your child in Language this kindergarten year?"). Responses ranged from $1=$ not at all good to $7=$ excellent. Cronbach's alpha were .79 for mathematics, .81 for language and .78 for general school performance.

\subsubsection{School Performance}

Children's school performance in kindergarten was estimated by their teachers. Teachers rated school performance for every single child whose parent participated in this study. The Performance school scale consisted of four items ('Rate your pupil general (or mathematics or language) school performance this kindergarten year'). Responses rated from $1=$ very poor to $7=$ excellent. Cronbach's alphas were .82, .84, and .87 for general school performance, mathematics, and language, respectively.

\subsubsection{Performance Expectations}

Parents' expectations concerning their children's school performance in the first primary school year were examined via the school performance scale, changing the verb tense ("How well do you expect your child to do in Language in the first primary school year?"). Responses ranged from $1=$ very poorly to $7=$ excellent. Cronbach's alpha were $.79, .85$, and .84 for general school performance, mathematics and language, respectively

\subsubsection{Personal Information}

The participants' personal information scale consisted of a set of questions relevant to their own personal factors, such as gender and occupation, and to their children's personal factors, such as age and gender.

\subsection{Procedure}

Data for each of the three subjects were gathered in the middle of a kindergarten year, to ensure that the participants had a good time to form an impression of the examined variables. The questionnaire was in person given to teachers, while it mailed to parents. Mothers or fathers or both jointly were asked to answer the questionnaire, considering that the responder parent is the significant other person to the child. 


\section{MInstitute Macrothink $_{\text {Int }}$}

International Journal of Social Science Research

ISSN 2327-5510

2020, Vol. 8, No. 2

The participants were explained the aim of this study, and they were assured of anonymity and confidentiality.

\section{Results}

\subsection{Parents'Attributions for their Children's School Performance in Kindergarten}

Preliminary analysis showed that children's performance at kindergarten was rated by their teachers from moderate to high in mathematics, Mean $=6.30, \mathrm{SD}=1.45$, in language, Mean $=6.18, \mathrm{SD}=1.55$, and in general, Mean $=6.10, \mathrm{SD}=1.60$.

To examine differences between the parental attributional dimensions for performance within school subject, three repeated measures ANOVAs, one for each school subject, were conducted, in which the four attributional dimensions were the within-subjects factor. Significant effect was found in mathematics, $F(3,147)=72.50, p<.01$, partial $\eta^{2}=.76$, in language, $\mathrm{F}(3,147)=91.00, \mathrm{p}<.01$, partial $\eta^{2}=.80$, and in generally school performance, $\mathrm{F}(3,147)=100.30, \mathrm{p}<.01$, partial $\eta^{2}=.85$. Furthermore, an inspection of the mean scores on Table 1 and post hoc pairwise comparisons showed that the parents attributed their children's good performance in mathematics, language and general to the children's stable and, mainly, internal and personal controllable factors than to the children's external controllable factors.

Table 1. Parents' attributions concerning their children's performance in kindergarten in generally school, mathematics and language

\begin{tabular}{lcccccr}
\hline & \multicolumn{2}{c}{$\begin{array}{c}\text { General school } \\
\text { performance }\end{array}$} & \multicolumn{2}{c}{$\begin{array}{c}\text { Mathematics } \\
\text { performance }\end{array}$} & \multicolumn{2}{c}{$\begin{array}{c}\text { Language } \\
\text { performance }\end{array}$} \\
\cline { 2 - 7 } & Mean & SD & Mean & SD & Mean & SD \\
\hline Locus of causality & 8.20 & .98 & 8.12 & 1.00 & 8.18 & .80 \\
Personal controllability & 8.00 & .85 & 8.05 & 1.35 & 8.20 & 1.00 \\
Stability & 7.65 & .88 & 7.65 & 1.25 & 7.85 & .98 \\
External controllability & 2.67 & 1.00 & 2.65 & 2.58 & 2.55 & 2.35 \\
\hline
\end{tabular}

The above findings in the most confirmed Hypotheses $1 \mathrm{a}$ and $1 \mathrm{~b}$.

\subsection{Effects of Parents' Perceptions of Their Children's Academic Ability on School} Performance, and on Subsequent Parental Attributions

The results from three bivariate regression analyses, one for each school subject (Table 2), showed that the higher parents perceived their children's ability, the better the children's subsequent performance. Conversely, the lower parents perceived their children's ability, the worse the children subsequently performed. This pattern was most powerful in language performance, $\mathrm{R}^{2}=.69$, followed by mathematics performance, $\mathrm{R}^{2}=.50$, and general performance, $\mathrm{R}^{2}=.13$.

Bivariate regression analyses with parents' perceptions of their children's ability as predictive 
variable and each of the parents' attributional dimensions for their children's performance at kindergarten as predicted variable were conducted in each school subject. These analyses revealed significant and positive effects of the perceived children's ability on parental attributions for their children's performance across the three school subjects. More precisely, the higher parents perceived their children's ability in mathematics, language and general school, the more internal to the children, controllable by the children, stable and external uncontrollable the attributions the parents made about their children's performance in the respective subject.

Furthermore, the findings regarding general school performance showed that the parents' perceptions of the children's ability accounted for a significant variance of the parental attributional dimension of locus of causality, $\mathrm{R}^{2}=.10$, personal controllability, $\mathrm{R}^{2}=.10$, external controllability, $\mathrm{R}^{2}=.08$, and, mainly, stability, $\mathrm{R}^{2}=.23$. Similarly, the parents' perceptions of their children's ability accounted for a significant variability of the parental attributional dimension of locus of causality, $\mathrm{R}^{2}=.22$, stability, $\mathrm{R}^{2}=.13$, external controllability, $\mathrm{R}^{2}=.07$, and, particularly, personal controllability, $\mathrm{R}^{2}=.36$, in performance in mathematics. Also, parents' perceptions of their children's ability explained an amount of the variance of their ewn attributions concerning the children's performance in language from $7 \%$ for external controllability, through $17 \%$ for personal controllability and $16 \%$ for stability, to $42 \%$ for locus of causality.

The above findings also indicated that the effects of parents' perceptions of their children's ability on parental attributions concerning the children's performance varied across school subjects, in unfavoring general performance. This pattern also varied within each school subject, with perceived ability being the most powerful formulator factor of locus of causality and personal controllability in language and mathematics, respectively.

Thus, Hypotheses 2a and 2b were mainly confirmed, and Hypothesis 3 was totally confirmed.

Table 2. Results from bivariate regression analyses for the effects of parents' perceptions of their children's ability on children's performance, and on the subsequent parental attributions

\begin{tabular}{lcccccccccc}
\hline & \multicolumn{3}{c}{$\begin{array}{c}\text { General school } \\
\text { performance }\end{array}$} & \multicolumn{3}{c}{$\begin{array}{c}\text { Mathematics } \\
\text { performance }\end{array}$} & \multicolumn{4}{c}{$\begin{array}{c}\text { Language } \\
\text { performance }\end{array}$} \\
\cline { 2 - 11 } & beta & $\mathrm{R}^{2}$ & \multicolumn{1}{c}{$\mathrm{F}$} & beta & $\mathrm{R}^{2}$ & $\mathrm{~F}$ & beta & $\mathrm{R}^{2}$ & $\mathrm{~F}$ \\
\hline School performance & .34 & .13 & 7.30 & .70 & .50 & 60.00 & .82 & .69 & 140.10 \\
Attributional dimensions & & & & & & & & & \\
Locus of causality & .33 & .10 & 5.78 & .45 & .22 & 14.20 & .65 & .42 & 39.20 \\
Personal controllability & .47 & .23 & 15.60 & .60 & .36 & 29.45 & .42 & .17 & 12.60 \\
Stability & .32 & .10 & 5.65 & .34 & .13 & 7.30 & .40 & .16 & 10.80 \\
External controllability & .27 & .08 & 4.20 & .25 & .07 & 3.90 & .27 & .07 & 4.20 \\
\hline
\end{tabular}

Note. $\mathrm{F}(1,148)>7.30, \mathrm{p}<.01, \mathrm{~F}(1,148)<7.30, \mathrm{p}<.05$. 


\section{Macrothink}

3.3 Effects of Parents'Perceptions of Their Children's Ability, Children's School Performance and Subsequent Parental Attributions on Performance Expectations

Hierarchical regression analyses, with enter method (Table 3), were performed within each school subject (mathematics, language, general). Parents' expectations concerning children's later school performance in the first primary school year was the criterion variable. Parents' attributions and their children's performance at the kindergarten were entered into the first step of the analysis, and their perceptions of children's ability were entered at the second step of the analysis. The results from these analyses, partly in line with Hypotheses $4 \mathrm{a}$ and $4 \mathrm{~b}$, revealed the following findings.

The three concepts, as a group, had a significant and positive effect in the formation of parents' expectations regarding their children's performance in the first primary school year in language, explaining $73 \%$ of the variance, in mathematics, explaining $56 \%$ of the variance, and in general, accounting for $33 \%$ of the variability.

The findings with respect to language, in addition, showed that the better the children's performance at kindergarten was, $\mathrm{b}=.12$, the more internal to the children's the attributions the parents made, $b=.16$, and, mainly, the higher the children's ability the parents estimated, $\mathrm{b}=.54$, the higher the parents' expectations concerning their children's performance in the first primary school year. Also, parents' estimation of their children's ability had an indirect effect, throughout the combination of the other two concepts, and a direct effect, beyond that affected by those factors on performance expectations, $\mathrm{R}^{2} \mathrm{ch}=.27$.

The results regarding mathematics, in addition, revealed that the children's performance, $b$ $=.30$, and the parents' perceptions of their children's ability, $\mathrm{b}=.55$, at kindergarten positively contributed into the generation of parental expectations, while parental attributional dimensions had no unique effect on it. Furthermore, parents' perceptions concerning their children's ability mediated the effect of performance in kindergarten on parental expectations about children's performance in the first year of primary school, $\operatorname{Rch}^{2}=.19$. 
Table 3. Results from hierarchical regression analyses for the effects of parents' perceptions of their children's ability, performance at kindergarten, and subsequent parental attributions on parental expectations concerning children's performance at the first primary school year

\begin{tabular}{|c|c|c|c|c|c|c|c|}
\hline Predictors & Steps & $\mathrm{R}^{2}$ & $\mathrm{Rch}^{2}$ & Fch & $\mathrm{F}$ & $\mathrm{b}$ & $\mathrm{t}$ \\
\hline & \multicolumn{5}{|c|}{ Language } & & \\
\hline Performance at kindergarten & & & & & & .16 & 4.50 \\
\hline Parental attributions & 1 & & & & & & \\
\hline -Locus of causality- & & .46 & & & 25.65 & .12 & 3.00 \\
\hline \multirow[t]{2}{*}{ Perceived children's ability } & 2 & .73 & .27 & 98.45 & 113.00 & .64 & 7.00 \\
\hline & \multicolumn{5}{|c|}{ Mathematics } & & \\
\hline Performance at kindergarten & & & & & & .30 & 2.85 \\
\hline Parental attributions & 1 & .37 & & & 35.60 & -- & -- \\
\hline \multirow[t]{2}{*}{ Perceived children's ability } & 2 & .56 & .19 & 22.95 & 36.80 & .55 & 5.00 \\
\hline & \multicolumn{5}{|c|}{ General school } & & \\
\hline Performance at kindergarten & & & & & & .51 & 4.55 \\
\hline Parental attributions & 1 & & & & & & \\
\hline -External controllability- & & .23 & & & 13.00 & .33 & 2.90 \\
\hline Perceived children's ability & 2 & .33 & -- & -- & 10.00 & -- & -- \\
\hline
\end{tabular}

Note. All F- and Fch- values are significant at the .01 level of significance; $--=p>.05$.

The findings regarding general school performance also indicated that the more the parents attributed their children's kindergarten performance to external controllable factors, $b=.51$, and the better the performance was, $b=.33$, the higher their expectations of good performance in primary school were. Furthermore, external controllability enhanced the effects of the other predictors on performance expectations, $\mathrm{Rch}^{2}=.19$, while perceived children's ability did not influence performance expectations uniquely.

\subsection{Effects of School Subject}

The above overall findings, confirming Hypothesis 5, showed that the academic domain differentiated the associations among the examined variable.

\section{Discussion}

The current study extends the literature by examining the parental attributions concerning children's general, mathematics and language school performance in kindergarten, the possible contributive role of parents' perceptions concerning their children's ability in the above performances and in the subsequent parental attributions, and the role of the three sets of variables in parents' expectations for their children's later school performance.

\subsection{Parental Attributions}

The findings regarding the parental attributional pattern for their children's achievement in kindergarten were in the most consistent with our expectations. Precisely, parents attributed their children's good performance to various attributional dimensions, supporting previous 
empirical evidence (Georgiou \& Tourva, 2007; Raty et al., 2002), showing the high importance of children academic achievement in their own personal identity (Sawrikar et al., 2019; Scott, 2018; Weiner, 2000, 2010), and confirming Miller's (1995) notation that parents' causal attributions begin to evolve in the early school years. Furthermore, by attributing the successful performance to stable, and, mainly, internal and controllable factors to their children, they enhanced their own aspirations for the children's success in the future, multiplied the possibilities to support the children, rose the chances of academic progress, and, simultaneously, enhanced their own role as good caretaker (Aunola et al., 2002; Dix \& Grusec, 1985; Fornander \& Kearney, 2019; Georgiou, 2010; Sawrikar \& Dadds, 2018; Weiner, 2010).

Against to some previous researches (Rytkönen et al., 2005), the participants did not address external or external controllable influences on their children's performance, such as teaching competence or teachers' support. This specific finding may reflect parental self-enhancing bias, in consistency with their tendency to stress dispositional to their children's factors when they explain good school performance (Goodnow, 1988; Natale et al., 2009). It may be also related to the young age of the children, since, when children grow older, other individuals, such as peers and teachers, play a more important role in children's performance (Boonk et al., 2018).

\subsection{The Role of Parents' Perceptions about Children's Ability in School Performance and Subsequent Parental Attributions}

As expected, the higher parents estimated their children's ability, the better the children performed in the respective school domain, and the higher the parental attributions to internal, stable, personal controllable and external uncontrollable to the children's factors were.

An interesting finding is a variability in the effect of parents' perceptions of their children's ability on attributions and performance between and within school subjects, in favoring language, and least favoring general school performance. It seems that parents were more confident in their children's capabilities in language than in mathematics, predicting more strongly the performance in the first than the later school subject. Also, in language, parental perceptions of their children's ability most influenced the locus of causality (internal to child's factors) than any other attributional dimension. It could be argued that parents, probably, perceived themselves as having a critical role to play in their children's language achievement, since at the kindergarten level parents are mainly involved in language-related activities (Garbacz et al., 2017; Saracho, 2002, 2007), and, hence, they credited their own parental role. In mathematics, the pattern of the effects of parents' beliefs on their own attributions (mainly, children's personal controllability) for the children's performance indicates that parents stressed the need for their children to try hard and put a lot of effort in order to achieve well, leading in later good performance (Sawrikar \& Dadds, 2018). Moreover, it might be assumed that parents communicate to the children different beliefs about math and language even at that pre-school years, which may influence children's later task- engagement and performance (Castro et al., 2015; Pomerantz et al., 2005). A critical point is whether and how parents communicate their beliefs to their children because some 
parents do not. Also, since the impact of parents' beliefs about their children's ability on stability attributions was low, it could be hypothesized these beliefs were temporary and may change as many changes take place in children's school-related activities, and as children grow up.

\subsection{Parents' Expectations Concerning Their Children's Later School Performance}

The findings regarding performance expectations revealed that the three sets of predictive factors had positive and complementary consequences for it. Although parental perceived children's ability was the most powerful predictor, children's past performance and the subsequent parental attributions accounted for a positive significant portion of the variance of performance expectations.

The found effect of children's performance in kindergarten on parents' expectations for future school performance corresponds to previous empirical evidence (Loughlin-Presnal \& Bierman, 2017) about the critical role of performance in it. This specific finding might contribute to understanding the procedure through which parents formulate their own beliefs about their children's school capabilities, and the crucial role of parent-teacher cooperation for the child's academic development.

Confirming our predictions, parents' both perceptions of their children's ability and attributions for children's achievement at kindergarten had a significant impact on their own expectations concerning the children's performance in the primary school fist year across language, mathematics and generally in school. These findings underline the high importance of such parental beliefs in that crucial period of children' academic life (Aunola et al., 2002; Bugental \& Happaney, 2002; Sy \& Schulenberg, 2005), and the necessity of forming positive parental beliefs via, for instance, positive praise for parents' efforts and positive evaluations for successful caregiving events (Sawrika et al., 2019; Scott \& Dadds, 2009).

The strong positive impact of parents' ability perceptions on performance expectations is consistent with Eccles and Wigfield (2002)'s model concerning intraindividual achievement (Rosenzweig et al., 2019). This finding also hinds that parents might have formulated the constant belief that high ability is needed in success. It should be noted that some such strong beliefs might increase children's performance-orientation, which, in turn, influences their subsequent performance (Mueller \& Dweck, 1998; Pomerantz et al., 2005). Performance-orientation does not facilitate young children to achieve academic excellence (Schunk \& Zimmerman, 2006).

Contrary, to our expectations, parental attributions had no unique contribution in their own expectations for their children's performance in mathematics, instead, the attributions effect was via ability perceptions. This could be partly attributed to the age of the participant. Specifically, according to previous research, students formulate strong beliefs about their ability in specific academic domains, as they move into upper grades of secondary school and as they get older (Boekaerts, 1999; Durkin, 2005; Harter, 1999; Jacobs, Lanza, Osgood, Eccles, \& Wigfield, 2002; Mac Iver, 1988). In addition, the Greek educational system emphasizes ability, particularly in secondary school. Parents, probably had a relatively 
constant belief about the importance of ability in the specific domains of language, and, in particular in mathematics, but not generally in school, and, subsequently, this belief influences performance expectations. However, future investigation should examine this speculation.

In language, in addition, the higher the parental internal attributions for children's performance, the higher their own expectations for children later school performance. Precisely, locus of causality was the solo attributional dimension that uniquely influenced the formation of performance expectations. This result partly corresponds to Wigfield and Eccles (2000), and to self-related factors that are needed for school success (Susperreguy et al., 2018).

In general school performance, additionally, parental attributions to external controllable to the children's factors positively contributed to parental performance expectations, showing parents' estimation that school success is not coming without help by significant others.

\subsection{Limitations, Implications of the Findings in Parents'Life and Future Research}

This study has some limitations that are needed to be considered in any attempt to generalize the present findings. The data for this research were gathered at one point in time. Future research should involve frequent assessments of parental attributions and beliefs concerning children's capabilities within a longitudinal framework to reliably examine change processes within the school year and education level. Future research should also investigate how these parental attributions and competence beliefs influence their emotions and real behavior towards children, and, hence, later academic achievement.

Despite the above limitations, the findings from the present study are meaningful. Parental attributions contributed to children's school performance in kindergarten, and in their own expectations for children's performance in grade one. Consequently, parents could be trained through programs that include a focus on parental attributions to optimize outcomes (Sawrikar et al., 2019; Weiner, 2010). The results also suggest that a potential mechanism of how parental attributions affect parents' expectations of children's future outcomes includes parental beliefs about the children's competence. Consequently, parents are needed to be helped develop positive beliefs by praising, for instance, their efforts and successful caregiving events (Kelly, Rossen, \& Cowan, 2018; Sawrika et al., 2019; Scott \& Dadds, 2009). Finally, the present findings indicated that parents' beliefs about kindergarten children differed among the school domains, suggesting that earlier parenting probably contributes to students' belief systems, which then impact their academic efforts and outcomes in the various school subjects.

\section{References}

Alves-Martins, M., \& Peixoto, F. (2000). Self-esteem, social identity and school achievement in adolescence. Psychology: The Journal of the Hellenic Psychological Society, 7, 278-289. https://doi.org/10.1080/01443410120101242

Aunola, K., Leskinen, E., Onatsu-Arvilommi, T., \& Nurmi, J.-E. (2002). Three methods for 
studying developmental change: A case of reading skills and self-concept. British Journal of Educational Psychology, 72, 343-364. https://doi.org/10.1348/000709902320634447

Azar, S. T. (1997). A cognitive behavioral approach to understanding and treating parents who physically abuse their children. In D. A. Wolfe, R. J. McMahon, \& R. D. Peters (Eds.), Child abuse: New directions in prevention and treatment across the lifespan (Vol. 4, pp. 79-101). Thousand Oaks, CA: Sage. https://doi.org/10.4135/9781452231938.n4

Beane, J. (1999). Sorting out the self-esteem controversy. Educational Leadership, 49(1), $25-30$.

Berndsen, M., \& Manstead, A. S. R. (2007). On the relationship between responsibility and guilt: Antecedent appraisal or elaborated appraisal? European Journal of Social Psychology, 37, 774-792. https://doi.org/10.1002/ejsp.397

Boekaerts, M. (1999). Motivated learning: Studying student situation transactional units. European Journal of Psychology of Education, 14(1), 41-55. https://doi.org/10.1007/BF03173110

Boonk, L., Gijselaers, H. J. M., Ritzen, H., \& Brand-Gruwela, S. (2018). A review of the relationship between parental involvement indicators and academic achievement. Educational Research Review, 24, 10-30. https://doi.org/10.1016/j.edurev.2018.02.001

Cashmore, J. A., \& Goodnow, J. J. (1986). Parent-child agreement on attributional beliefs. International Journal of Behavioral Development, 9, 191-204. https://doi.org/10.1177/016502548600900204

Castro, M., Expósito-Casas, E., López-Martín, E., Lizasoain, L., Navarro-Asencio, E., Darling, N., \& Steinberg, L. (1993). Parenting style as context: An integrative model. Psychological Bulletin, 113, 487-496. https://doi.org/10.1016/j.edurev.2015.01.002

Dix, T. H., \& Grusec, J. E. (1985). Parent attribution processes in the socialization of children. In I. E. Siegel (Ed.), Parental belief systems: The psychological consequences for children (pp. 177-199). Hillsdale, NJ: Erlbaum.

Dix, T., \& Lochman, J. E. (1990). Social cognition and negative reactions to children: A comparison of mothers of aggressive and nonaggressive boys. Journal of Social and Clinical Psychology, 9(4), 418-438. https://doi.org/10.1521/jscp.1990.9.4.418

Duckworth, A. L., Peterson, C., Matthews, M. D., \& Kelly, D. R. (2007). Grit: Perseverance and passion for long-term goals. Journal of Personality and Social Psychology, 92(6), 1087-1101. https://doi.org/10.1037/0022-3514.92.6.1087

Dunton, K., McDevitt, T., \& Hess, R. (1988). Origins of mothers' attributions about their daughters' and sons' performance in mathematics in sixth grade. Merrill-Palmer Quarterly, $34,47-70$.

Durkin, K. (2005). Adolescence: An introduction. London: Blackwell.

Eccles, J. S. (2009). Who am I and what am I going to do with my life? Personal and 
collective identities as motivators of action. Educational Psychology, 44, 78-89. https://doi.org/10.1080/00461520902832368

Eccles, J. S., \& Wigfield, A. (2002). Motivational beliefs, values and goals. Annual Review of Psychology, 53, 109-132. https://doi.org/10.1146/annurev.psych.53.100901.135153

Efklides, A. (2001). Metacognitive experiences in problem solving: Metacognition, cognition and self- regulation. In A. Efklides, J. Kuhl \& R. M. Sorrrentino (Eds.), Trends and prospects in motivation research (pp. 297-323). Dordrecht, The Netherands: Kluwer. https://doi.org/10.1007/0-306-47676-2_16

Englund, M. M., Luckner, A. E., Whaley, G. J. L., \& Egeland, B. (2004). Children's achievement in early elementary school: Longitudinal effects of parental involvement, expectations, and quality of assistance. Journal of Educational Psychology, 96(4), 723-730. https://doi.org/10.1037/0022-0663.96.4.723

Epstein, J. (1992). School and family partnerships. In M. Alkin (Ed.), Encyclopedia of Educational Research (6th ed., pp. 1139-1151). New York: MacMillan.

Epstein, J. L., \& Dauber, S. L. (1991). School programs and teacher practices of parent involvement in innercity elementary and middle schools. Elementary School Journal, 91(3), 289-305. https://doi.org/10.1086/461656

Fan, X. (2001). Parental involvement and students' academic achievement: A growth modeling analysis. Journal of Experimental Education, 70, 27-61. https://doi.org/10.1080/00220970109599497

Fan, X., \& Chen, M. (2001). Parental Involvement and students' Academic Achievement: A Meta-Analysis. Educational Psychology Review, 13, 1-22. https://doi.org/10.1023/A:1009048817385

Fornander, M. J., \& Kearney, C. A. (2019). Family environment variables as predictors of school absenteeism severity at multiple levels: ensemble and classification and regression tree analysis. Frontiers in Psychology, 10, 2381. https://doi.org/10.3389/fpsyg.2019.02381

Garbacz, S. A., Herman, K. C., Thompson, A. M., \& Reinke, W. M. (2017). Family engagement in education and intervention: implementation and evaluation to maximize family, school, and student outcomes. Journal of School Psychology, 62, 1-10. https://doi.org/10.1016/j.jsp.2017.04.002

Gaviria, J. J. (2015). Parental involvement on student academic achievement: A meta-analysis. Education Research Review, 14, 33-46. https://doi.org/10.1016/j.edurev.2015.01.002

Georgiou, S. N. (2010). Parental attributions as predictors of involvement and influences on child achievement. British Journal of Educational Psychology, 69(3), 409-429. https://doi.org/10.1348/000709999157806

Georgiou, S., \& Tourva, A. (2007). Parental attributions and parental involvement. Social Psychology of Education, 10(4), 473-482. https://doi.org/10.1007/s11218-007-9029-8 
Goodnow, J. J. (1988). Parents' ideas, actions, and feelings: Models and methods from developmental and social psychology. Child Development, 59(2), 286-320. https://doi.org/10.2307/1130312

Graham, S., \& Weiner, B. (1991). Testing Judgments about Attribution-Emotion-Action Linkages: A Lifespan Approach. Social Cognition, 9, 254-276. https://doi.org/10.1521/soco.1991.9.3.254

Gretarsson, S. J., \& Gelfand, D. M. (1988). Mothers' attributions regarding their children's social behavior and personality characteristics. Developmental Psychology, 24(2), 264-269. https://doi.org/10.1037/0012-1649.24.2.264

Gut, J., Reimann G., \& Grob, G. (2013). A contextualized view on long-term predictors of academic performance. Journal of Educational Psychology, 105(2), 436-443. https://doi.org/10.1037/a0031503

Harter, S. (1999). The construction of the self: A developmental perspective. New York: Guilford.

Herbert, J., \& Stipek, D. (2005). The emergence of gender differences in children's perceptions of their academic competence. Applied Developmental Psychology, 26, 276-295. https://doi.org/10.1016/j.appdev.2005.02.007

Herrera. L., Al-Lal, M., \& Mohamed, L. (2020). Academic achievement, self-concept, personality and emotional intelligence in primary education. Analysis by gender and cultural group. Frontiers in Psychology, 10, 3075. https://doi.org/ 10.3389/fpsyg.2019.03075

Hill, N. E., \& Craft, S. A. (2003). Parent-school involvement and school performance: Mediated pathways among socioeconomically comparable African American and Euro-American families. Journal of Educational Psychology, 95(1), 74-83. https://doi.org/10.1037/0022-0663.95.1.74

Hill, N. E., \& Taylor, L. C. (2004). Parental school involvement and children's academic achievement: Pragmatics and issues. Current Directions in Psychological Science, 13, 161-164. https://doi.org/10.1111/j.0963-7214.2004.00298x

Holloway, S. D., \& Hess, R. D. (1985). Mothers' and teachers' attributions about children's mathematics performance. In I. E. Sigel (Ed.), Parental belief systems: The psychological consequences for children (pp. 177-199). Hillsdale, NJ: Erlbaum.

Hong, S., \& Ho, H. Z. (2005). Direct and indirect longitudinal effects of parental involvement on student achievement: Second-order latent growth modeling across ethnic groups. Journal of Educational Psychology, 97(1), 32-42. https://doi.org/10.1037/0022-0663.97.1.32

Hutchinson, A. J., \& Yates, G. C. R. (2008). Maternal goal factors in adaptive and maladaptive childhood perfectionism. Educational Psychology, 28, 795-808. https://doi.org/10.1080/01443410802320402

Ishak, Z., Low, S. F., \& Lau, P. L. (2011). Parenting Style as a Moderator for Students' 
Academic Achievement. Journal of Science Education and Technology, 21, 487-493. (2012). https://doi.org/10.1007/s10956-011-9340-1

Jacobs, J. E., Lanza, S., Osgood, D. W., Eccles, J., \& Wigfield, A. (2002). Changes in children's self-competence and values: Gender and domain differences across grades one through twelve. Child Development, 37, 509-527. https://doi.org/10.1111/1467-8624.00421.

Jeynes, W. H. (2007). The relationship between parental involvement and urban secondary school student academic achievement: A meta-analysis. Urban Education, 42, 82-110. https://doi.org/10.1177/0042085906293818

Johnston, C., Hommersen, P., \& Seipp, C. M. (2009). Maternal attributions and child oppositional behavior: A longitudinal study of boys with and without attention-deficit/hyperactivity disorder. Journal of Consulting and Clinical Psychology, 77(1), 189-195. https://doi.org/10.1037/a0014065

Jones, T. L., \& Prinz, R. J. (2005). Potential roles of parental self-efficacy in parent and child adjustment: A review. Clinical Psychology Review, 25, 341-363. https://doi.org/10.1016/j.cpr.2004.12.004

Kamins, M. L., \& Dweck, C. S. (1999). Person versus process praise and criticism: Implications for contingent self-worth and coping. Developmental Psychology, 35, 835-847. https://doi.org/10.1037//0012-1649.35.3.835

Kaplan, D. S., Liu, X., \& Kaplan, H. B. (2001). Influence of parents' self-feelings and expectations on children's academic performance. Journal of Educational Research, 94, 360-370. https://doi.org/10.1080/00220670109598773

Kelly, J., Rossen, E., \& Cowan, K. C. (2018). Supporting families to support students. Education Leadership, 75, 62-69. https://doi.org/10.4324/9780203417003-13

Kinlaw, C. R., Kurtz-Costes, B., \& Goldman-Fraser, J. (2001). Mothers' achievement beliefs and behaviors and their children's school readiness: A cultural comparison. Journal of Applied Developmental Psychology, 22, 493-506. https://doi.org/10.1080/00220670109598773

Lee, S. M., Daniels, M. H., \& Kissinger, D. B. (2006). Parental influences on adolescent adjustment: Parenting styles versus parenting practices. The Family Journal: Counselling and Therapy for Couples and Families, 14, 253-259. https://doi.org/10.1177/1066480706287654

Loughlin-Presnal, J. E., \& Bierman, K. L. (2017). Promoting parent academic expectations predicts improved school outcomes for low-income children entering kindergarten. Journal of School Psychology, 62, 67-80. https://doi.org/10.1016/j.jsp.2017.03.007

Ma, X., Shen, J., Krenn, H. Y., Hu, S., \& Yuan, J. (2016). A Meta-Analysis of the relationship between learning outcomes and parental involvement during early childhood education and early elementary education. Educational Psychology Review, 28, 771-801. https://doi.org/10.1007/s10648-015-9351-1 
Mac Iver, D. (1988). Classroom environments and the stratification of pupils' ability perceptions. Journal of Educational Psychology, 80, 495-505. https://doi.org/10.1037/0022-0663.80.4.495

Marchant, G. J., Sharon, E., Paulson, \& Rothlisberg, B. A. (2001). Relations of middle school students' perceptions of family and school contexts with academic achievement. Psychology in the Schools, 38(6), 505-519. https://doi.org/10.1002/pits.1039

Martini, F., \& Sénéchal, M. (2012). Learning literacy skills at home: Parent teaching, expectations, and child interest. Canadian Journal of Behavioural Science, 44(3), 210-221. https://doi.org/10.1037/a0026758

Mau, W. C. (1997). Parental influences on the high school students' academic achievement: ... Attributions of academic success and failure: A comparison of Asian immigrants, Asian Americans, and White Americans. Psychology in the Schools, 34(3), 267-277.

https://doi.org/10.1002/(SICI)1520-6807(199707)34:3<267::AID-PITS9>3.0.CO;2-L

Meyer, J., Fleckenstein, J., \& Köller, O. (2019). Expectancy value interactions and academic achievement: Differential relationships with achievement measures. Contemporary Educational Psychology, 58, 58-74. https://doi.org/10.1016/j.cedpsych.2019.01.006

Miedel, W. T., \& Reynolds, A. J. (1999). Parent involvement in early intervention for disadvantaged children. Does it matter? Journal of School Psychology, 37(4), 379-402. https://doi.org/10.1016/S0022-4405(99)00023-0

Miller, S. A. (1995). Parents' attributions for their children's behavior. Child Development, 66, 1557-1584. https://doi.org/10.2307/1131897

Mueller, C. M., \& Dweck, C. S. (1998). Praise for intelligence can undermine children's motivation and performance. Journal of Personality and Social Psychology, 75, 33-52.

Nagy, G., Trautwein, U., Baumert, J., Koller, O., \& Garrett, J. (2006). Gender and course selection in upper secondary education: Effects of academic self-concept and intrinsic value. Educational Research and Evaluation, 21(4), 323-345. https://doi.org/10.1080/13803610600765687

Natale, K., Aunola, K., \& Nurmi, J. E. (2009). Children's school performance and their parents' causal attributions to ability and effort: A longitudinal study. Journal of Applied Developmental Psychology, 30, 14-22. https://doi.org/10.1016/j.appdev.2008.10.002

Nix, R. L., Pinderhughes, E. E., Dodge, K. A., Bates, J. E., Pettit, S., \& McFadyen-Ketchum, S. A. (1999). The relation between mothers' hostile attribution tendencies and children's externalizing behavior problems: The mediating role of mothers' harsh discipline practices. Child Development, 70(4), 896-909. https://doi.org/10.1016/j.appdev.2008.10.002

Nuutila, K., Tuominen, H., Tapola A., Vainikainen, M. P., \& Niemivirta, M. (2018). Consistency, longitudinal stability, and predictions of elementary school students' task interest, success expectancy, and performance in mathematics. Learning and Instruction, 56, 
73-83. https://doi.org/10.1016/j.learninstruc.2018.04.003

Okpala, C. O., Okpala, A. O., \& Smith, F. E. (2001). Parental involvement, instructional expenditures, family socioeconomic attributes, and student achievement. Journal of Educational Research, 95, 110 -115. https://doi.org/10.1080/00220670109596579

Parsons, J. E., Adler, T. F., \& Kaczala, C. M. (1982). Socialization of achievement attitudes and beliefs: Parental influences. Child Development, 53, 310-321. https://doi.org/10.2307/1128973

Phillipson, S., \& Phillipson, S. N. (2007). Academic expectations, belief of ability, and involvement by parents as predictors of child achievement: A cross - cultural comparison. Educational Psychology: An International Journal of Experimental Educational Psychology, 27(3), 329-348. https://doi.org/10.1080/01443410601104130

Pintrich, P. R., \& Schunk, D. (2002). Motivation in education: Theory, research, and applications (2nd ed.). Upper Saddle River, NJ: Prentice Hall.

Pomerantz, E. M., \& Dong, W. (2006). Effects of mothers' perceptions of children's competence: The moderating role of mothers' theories of competence. Developmental Psychology, 42(5), 950-961. https://doi.org/10.1037/0012-1649.42.5.950

Pomerantz, E. M., Grolnick, W. S., \& Price, C. E. (2005). The role of parents in how children approach achievement: A dynamic process perspective. In A. J. Elliot \& C. S. Dweck (Eds.), Handbook of competence and motivation (pp. 229-278). New York: Guilford.

Racz, S. J., Putnick, D. L., Esposito, G., \& Bornstein, M. H. (2019). Children's academic, artistic, and athletic competencies: successes are in the eye of the beholder. Frontiers in Psychology. https://doi.org/10.3389/fpsyg.2019.02225

Räty, H., Vänskä, J., Kasanen, K., \& Kärkkäinen, R. (2002). Parents' explanations of their child's performance in mathematics and reading: A replication and extension of Yee and Eccles. Sex Roles, 46, 121-128. https://doi.org/10.1023/A:1016573627828

Redding, S. (2006). The mega system: Deciding, learning, connecting. Lincoln, Il: Academic Development Institute.

Rimm-Kaufman, S. E, Pianta, R. C., Cox, M. J., \& Bradley, M. J. (2003). Teacher rated family involvement and children's social and academic outcomes in kindergarten. Early Education \& Development, 14, 179-198. https://doi.org/10.1207/s15566935eed1402_3

Rosenzweig, E., Wigfield, A., \& Eccles, J. (2019). Expectancy-Value theory and its relevance for student motivation and learning. In K. Renninger \& S. Hidi (Authors), The Cambridge Handbook of Motivation and Learning (Cambridge Handbooks in Psychology, pp. 617-644). Cambridge: Cambridge University Press. https://doi.org/10.1017/9781316823279.026

Rytkonen, K., Aunola, K., \& Nurmi, J. (2005). Parents' Causal Attributions Concerning Children's School Achievement: A Longitudinal Study. Merrill-Palmer Quarterly, 51(4), 494-522. https://doi.org/10.1353/mpq.2005.0027. 
Saracho, O. N. (2002). Family literacy: Exploring family teachings. Early Child Development and Care, 172, 113-122. https://doi.org/10.1080/03004430210886

Saracho, O. N. (2007). Fathers and young children's literacy experiences in a family environment. Early Child Development and Care, 177, 403-415. https://doi.org/10.1080/03004430600563034

Sawrikar, V., \& Dadds, M. (2018). What role for parental attributions in parenting interventions for child conduct problems? Advances from research into practice. Clinical Child and Family Psychology Review, 21(1), 41-56. https://doi.org/10.1007/s10567-017-0243-4

Sawrikar, V., Hawes, D. J., Moul, C., \& Dadds, M. R. (2019). How do mothers' parental attributions affect child outcomes from a positive parenting intervention? A mediation study. Child Psychiatry and Human Development. https://doi.org/10.1007/s 10578-019-00942-0

Schunk, D. H., \& Zimmerman, B. J. (2006). Competence and control beliefs: distinguishing the means and ends. In P. A. Alexander \& P. H. Winne (Eds.), Handbook of educational psychology (pp. 349-367). Lawrence Erlbaum.

Scott, A. M. (2018). Parents' beliefs about children. London, U.K.: Oxford University Press.

Scott, S., \& Dadds, M. R. (2009). Practitioner review: When parent training doesn't work: Theory-driven clinical strategies. Journal of Child Psychology and Psychiatry, 50(12), 1441-1450. https://doi.org/10.1111/j.1469-7610.2009.02161.x.

Sewasew, D., \& Schroeders, U. (2019). The developmental interplay of academic self-concept and achievement within and across domains among primary school students. $\begin{array}{llll}\text { Contemporary } \quad \text { Educational } & \text { Psychology, } & \text { 204, }\end{array}$ https://doi.org/10.1016/j.cedpsych.2019.03.009

Soenens, B., Duriez, B., Vansteenkiste, M., \& Goossens, L. (2007). The Intergenerational Transmission of Empathy-Related Responding in Adolescence: The Role of Maternal Support. Personality and Social Psychology Bulletin, 33(3), 299-311. https://doi.org/10.1177/0146167206296300

Stephanou, G. (2004). Effects of ability self-perception, perceived task-difficulty, performance expectations and importance of performance on performance and attributions in specific academic domains. In J. Baumert, H. W. Marsh, U. Trautwein, \& G. E. Richards (Eds), Proceedings of the 3rd International SELF Research Conference: Self-Concept, Motivation and Identity (CD form). Berlin, Germany: Max Planck Institute for Human Development. http://www.self.ox.ac.uk

Stephanou, G. (2006). Effects of cognitive factors and teacher effectiveness on students' academic emotions and performance. In R. G. Graven, J. Eccles, \& M. Tr. Ha (Eds), Proceedings of the 4rd International SELF Research Conference: Self-Concept, Motivation, Social and Personal Identity for the 21tst Century. Sydney, Australia: SELF Research Center, University of Western Sydney. Retrieved from 
http://self.uws.edu.auConferences/2006_Stephanou.pdf

Stephanou, G. (2008). Students' value beliefs, performance expectations, and school performance: The effect of school subject and gender. Hellenic Journal of Psychology: The Journal of the Psychological Society of Northern Greece, 5, 231-257.

Stephanou, G. (2012). Students' School Performance in Language and Mathematics: Effects of Hope on Attributions, Emotions and Performance Expectations. International Journal of Psychological Studies, 4(2), 92-119. https://doi.org/10.5539/ijps.v4n2p93

Stephanou, G., \& Mpiontini, M. (2017). Metacognitive knowledge and metacognitive regulation in self-regulatory learning style, and in its effects on performance expectation and subsequent performance across diverse school subjects. Psychology, 8, 1941-1975. https://doi.org/10.4236/psych.2017.812125

Stevenson, D. L., \& Baker, D. P. (1987). The family-school relation and the child's school performance. Special issue: Schools and development. Child Development, 58, 1348-1357. https://doi.org/10.2307/1130626

Strassberg, Z. (1995). Social information processing in compliance situations by mothers of behavior-problem boys. Child Development, 66(2), 376-389. https://doi.org/10.2307/1131584

Susperreguy, M. I., Davis-Kean, P. E., Duckworth, K., \& Chen, M. (2017). Self-concept predicts academic achievement across levels of the achievement distribution: Domain specificity for math and reading. Child Development, 89(6), 2196-2214. https://doi.org/10.1111/cdev.12924

Sy, S. R., \& Schulenberg, J. E. (2005). Parent beliefs and children's achievement trajectories during the transition to school in Asian American and European American families. International Journal of Behavioral Development, 29, 505-515. https://doi.org/10.1177/01650250500147329

Taylor, L. C., Clayton, J. D., \& Rowley, S. J. (2004). Academic socialization: Understanding parental influence on children's school related development in the early years. Review of General Psychology, 8(3), 163-178. https://doi.org/10.1037/1089-2680.8.3.163

Tomasetto, C., Mirisola, A., Galdi, S., \& Cadinu, M. (2015). Parents' math-gender stereotypes, children's self-perception of ability, and children's appraisal of parents' evaluations in 6-year-olds. Contemporary Educational Psychology, 42, 186-198. https://doi.org/10.1016/j.cedpsych.2015.06.007

Topor, D. R., Keane, S. P., Shelton, T. L., \& Calkins S. D. (2010). Parent involvement and student academic performance: A multiple mediational analysis. Journal of Prevention \& Intervention in the Community, 38, 183-197. https://doi.org/10.1080/10852352.2010.486297

Urdan, T., Solek, M., \& Schoenfelder, E. (2007). Students' perceptions of family influences on their academic motivation: A qualitative analysis. European Journal of Psychology of Education, 22, 7-21. https://doi.org/10.1007/BF03173686 
Wand, H., \& Hall, N. C. (2018). A Systematic Review of Teachers' Causal Attributions: Prevalence, Correlates, and Consequences. Frontiers in Psychology, 9, 2305. https://doi.org/10.3389/fpsyg.2018.02305

Weiner, B. (1992). Human motivation. Metaphors, theories, and research. Newbury Park, CA: Sage.

Weiner, B. (2000). Intrapersonal and interpersonal theories of motivation from an attributional perspective. Educational Psychology Review, 12, 1-14. https://doi.org/10.1023/A:1009017532121

Weiner, B. (2001). An attributional approach to perceived responsibility. In A. E. Auhangen \& H. W. Bierhoff (Eds.), Responsibility: The Many Faces of a Social Phenomenon (pp. 49-60). New York, NY: Routledge.

Weiner, B. (2003). The classroom as a courtroom. Social Psychology of Education, 6, 3-15. https://doi.org/10.1023/A:1021736217048

Weiner, B. (2005). Motivation from an attribution perspective and the social psychology of perceived competence. In A. J. Elliot \& C. S. Dweck (Eds.), Handbook of Competence and Motivation (pp. 73-84). New York: Guilford.

Weiner, B. (2006). Social motivation, justice, and the moral emotions: An attributional approach. Mahwah, N. J: Erlbaum. https://doi.org/10.4324/9781410615749

Weiner, B. (2010). The development of an attribution-based theory of motivation: a history of ideas. Educational Psychology, 45, 28-36. https://doi.org/10.1080/00461520903433596

White, K. R., Taylor, J. J., \& Moss, V. D. (1992). Does research support claims about the benefits of involving parents in early intervention programs? Review of Educational Research, 62, 91-125. https://doi.org/10.2307/1170719

Wigfield, A., Byrnes, J. P., \& Eccles, J. S. (2006). Development during early and middle adolescence. In P. Alexander \& P. Winne (Eds.), Handbook of educational psychology (2nd ed., pp. 87-113). New York: Macmillan Publishing.

Wigfield, A, \& Eccles, J. (1992). The development of achievement task values: a theoretical analysis. Developmental Review, 265-310. https://doi.org/10.1016/0273-2297(92)90011-P

Wigfield, A., \& Eccles, J. (2000). Expectancy-value theory of achievement motivation. Contemporary Educational Psychology, 25, 68-81. https://doi.org/10.1006/ceps.1999.1015

Wigfield, A., \& Eccles, J. (2002). The development of competence beliefs and values from childhood through adolescence. In A. Wigfield \& J. S. Eccles (Eds.), Development of achievement motivation (pp. 92-120). San Diego, CA: Academic.

Yee, D. K., \& Eccles, J. S. (1988). Parent perceptions and attributions for children's math achievement. Sex Roles, 19, 317-333. https://doi.org/10.1007/BF00289840. 


\section{Macrothink}

International Journal of Social Science Research

ISSN 2327-5510 2020, Vol. 8, No. 2

Zentner, M. \& Renaud, O. (2007). Origins of adolescents' ideal self: An intergenerational perspective. Journal of Personality and Social Psychology, 92(3), 557-574. https://doi.org/10.1037/0022-3514.92.3.557

\section{Copyrights}

Copyright for this article is retained by the author(s), with first publication rights granted to the journal.

This is an open-access article distributed under the terms and conditions of the Creative Commons Attribution license (http://creativecommons.org/licenses/by/4.0/). 